\title{
Síla odrazu běžců na lyžích u vybraných technik běhu
}

\section{The Cross Country Skiers Push-off Force explored on selected Techniques}

\author{
Pavel Korvas ${ }^{1}$, Jiří Suchý ${ }^{2}$ \\ ${ }^{1}$ Fakulta sportovních studií Masarykovy univerzity, Brno \\ ${ }^{2}$ Fakulta tělesné výchovy a sportu Univerzity Karlovy, Praha
}

\begin{abstract}
Abstrakt
Př́spèvek je deskriptivní studií zabývající se základními dynamickými charakteristikami hlavních technik volného způsobu běhu na lyžích. Byla měřena a analyzována síla, kterou běžci vytvárí dolními končetinami při odrazu u bruslení oboustranného dvoudobého a jednodobého, a zjištována doba odrazu. Měřní bylo provedeno pomocí systému Pedar (Novel, SRN). Sledovanou skupinou byli běžci na úrovni I. výkonnostní třídy, kteři se umistili do 25. místa v žebřičcu SLČR. Byly zjištěny rozdílné hodnoty maximální síly při odrazu mezi sledovanými technikami, vyšši síla byla vždy zjištěna při bruslení na rovině ve srovnání se stoupáním, a to jak pro tréninkovou, tak i závodní rychlost. Prưmèrné hodnoty maximální síly na rovině u bruslení dvoudobého dosáhly 1,2-1,5násobku hmotnosti běžcu, u jednodobého v rozmezí 1,1-1,4násobků hmotnosti. Ve stoupání ćinily tyto hodnoty 1,2-1,4násobek hmotnosti pro bruslení oboustranné dvoudobé a 1-1,2 násobek pro jednodobé.
\end{abstract}

\begin{abstract}
The contribution is the descriptive study which is dealing with the basic kinetic characteristics of main cross country ski skating techniques. We observed and analysed the leg force during the stroke for open field skating or V1 and V2 skating. Next we studied the time of the stroke (kick). The measurement was made with the help of the system Pedar [Novel, GER]. Our observed group created the high performance level competitors, who's placed till 25th in the SLCR ranking. We found out the various figures of maximal force for both technique, usually higher for open field and V1 technique than for V2 skating, the higher force during the skating on the flat terrain than on the slope for training and race speed. The average value of maximal force on the flat terrain during open field or V1 skating were 1,2-1,5 multiple of body weight (BW), for $V 2$ skating we found 1,1-1,4 (BW). In the uphill the value were 1,2-1,4 (BW) for open field or V1 skating and $1-1,2(B W)$ for $V 2$.
\end{abstract}

Klíčováslova: bruslení oboustranné dvoudobé, bruslení oboustranné jednodobé, doba odrazu, dynamická analýza, odraz, síla odrazu,

Key words: $\quad$ open field skating, V1 skating, V2 skating, time of stroke (kick), kinetic analyse, stroke (kick), force of the stroke (kick)

\section{Úvod}

Běh na lyžích zaznamenal za posledních 20-30 let významný rozvoj sportovní výkonnosti, který lze hodnotit zejména stálým zvyšováním rychlosti špičkových závodníků na světových soutěžích (Korvas 2009, Hottenrott 2004). Tento progres má svůj základ především v rozvoji technologií lyží i tratí a jejich úpravy, stálým zlepšováním techniky a efektivity pohybu a samozřejmě zvyšováním úrovně trénovanosti, především silové vytrvalosti.

Běh na lyžích je kvadrupedální pohybová činnost, při které tvoří hybné síly ve směru pohybu jak dolní, tak horní končetiny, a částečně i trup. Hlavní podíl na produkci hybné síly u obou způsobů běhu a jejich technik na většině trati mají dolní končetiny. Podle Belliziho (1998) lyžaři vytváří při běhu střídavém dvoudobém za různých rychlostí 69 \% dopředné energie dolními končetinami a 31 \% pažemi. Ovšem u volného způsobu běhu ve stoupání může být tento poměr až 50:50 \% (Street 1989, Ilavský 2005, etc). S ohledem na terén je maximální vertikální síla vytvářená dolními končetinami při odrazu u střídavé- 
ho běhu dvoudobého na úrovni 1,6-3násobku tělesné hmotnosti. Absolutní hodnoty těchto sil dosahují u špičkových závodníků velikosti až 1500-2000 N (Komi, Norman 1987, Rusko 2003). Př́i volném způsobu běhu dosahuje maximální kolmá síla při odrazu 0,8-2násobek hmotnosti těla běžce, to znamená 600-1300 N (např. Lindinger 1995, Rusko 2003). Sílu při odrazu, která se vytváří dolní končetinou, není v současné době obtížné laboratorně změřit. Pokud sílu zjištujeme při odrazu u sportů v př́rodě, př̀ specifické pohybové činnosti v terénu, je to záležitost více komplikovaná, zejména pokud se jedná o běh na lyžích. V historii výzkumných šetření kinetických parametrů odrazu běžce na lyžích provedli experimentální měření pro klasický způsob běhu např. Ekstrom (1981), Komi (1987), Leppavuori (1993) nebo u volného způsobu běhu Lindinger (1995). Výsledky těchto šetření nebyly zobecňovány pro malý počet probandů. U běžců na lyžích je síla působící na lyži při odrazu zjištována pomocí různé přístrojové techniky, mezi niž patří mobilní systém fy Novel (GER, Lindinger, 1995), telemetrický deskový systém upevněný na lyžích pod vázáním běžce (Ekstrom 1981) nebo tenzometrické desky instalované pod sněhem na lyžařské trati (Komi 1987, Leppavuori 1993).

Cílem výzkumu bylo provést deskriptivní studii, která umožní analyzovat rozdíly dynamických ukazatelů dvou nejčastěji používaných technik volného způsobu běhu a srovnat dosažené výsledky s jinými studiemi.

\section{Metodika}

Provedli jsme studii odrazu dvou technik volného způsobů běhu na lyžích, běhu oboustranného jednodobého a dvoudobého. Výsledky měření byly využity pro srovnání s jinými studiemi. Kolmá síla vytvářená dolní končetinou a působící na podložku v průběhu odrazu byla zaznamenána pomocí mobilního systému Pedar (fy Novel, GER) prostřednictvím speciálních vložek do bot, které obsahují 99 senzorů rovnoměrně rozložených na celou jejich plochu. Př́stroj dále obsahuje datový záznamník, flash kartu a soupravu kabelů. Záznam byl proveden na frekvenci $50 \mathrm{~Hz}$ pomocí speciálního softwaru firmy Novel. Kalibrace vložek obuvi je prováděna s použitím cejchovacího zařízení přístroje Pedar. Síly vytvářené dolními končetinami lyžaře a přenášené na lyže byly zaznamenány pro oba způsoby běhu u pěti kompletních pohybových cyklů v délce úseku do $30 \mathrm{~m}$. Pro vyhodnocení zatížení byla použita maska pro celou plochu vložek. Pracovali jsme s průběžnými hodnotami generovanými po $0,02 \mathrm{~s}$, ze kterých byly vypočítány hodnoty síly $\mathrm{z}$ fáze odrazu a zjištěna hodnota maximálního impulzu síly v průběhu sledovaných cyklů. Měření probíhalo na upravené standardní běžecké trati, na rovinatém úseku a ve stoupání o sklonu $7^{\circ}$ stupňů. Při jednotlivých měřeních každý běžec absolvoval sledovaný úsek tréninkovou i závodní rychlostí. Rychlosti byly ponechány na citu závodníka, tréninková rychlost byla definována jako rychlost běhu při rozvoji aerobní vytrvalosti dlouhodobého charakteru. Měření bylo provedeno v průběhu února 2011 na standardních tratích v Novém Městě na Moravě, podkladem byl umělý sníh, který zaručoval stabilní podmínky pro měření.

Tab.1 Rozsah rychlostí běhu u sledované skupiny při měření

\begin{tabular}{|c|c|c|c|}
\hline Technika / rychlost běhu & & $\begin{array}{c}\text { Tréninková rych- } \\
\text { lost }(\mathbf{m} / \mathbf{s})\end{array}$ & $\begin{array}{c}\text { Závodní rychlost } \\
(\mathbf{m} / \mathbf{s})\end{array}$ \\
\hline Bruslení oboustranné jednodobé & Rovina & $4,2-4,9$ & $7,2-7,7$ \\
\hline Bruslení oboustranné jednodobé & Kopec & $3,0-3,4$ & $5,1-5,5$ \\
\hline Bruslení oboustranné dvoudobé & Rovina & $4,3-4,7$ & $7,0-7,6$ \\
\hline Bruslení oboustranné dvoudobé & Kopec & $3,2-3,7$ & $5,2-5,5$ \\
\hline
\end{tabular}

V průběhu pilotní studie byla testována skupina 6 kvalitních českých běžců, kteří pravidelně trénují a v žebříčku kategorie dospělých se v roce výzkumu umístili do 25 . místa. Průměrný věk skupiny byl 19,8 let, výška 180,8 cm, hmotnost 75,7 kg s průměrnou dobou pravidelného tréninku 8,5 let. Členové skupiny závodili v roce výzkumu v kategorii junioři nebo dospělí. 


\section{Výsledky}

Z popsaného měření jsme získali průměrné hodnoty maximální síly vznikající na chodidle běžců, které jsou uvedeny v tabulce 1 .

Tab. 1 Průměrné hodnoty maximální síly na chodidle u výzkumného souboru

\begin{tabular}{|c|c|c|c|}
\cline { 2 - 4 } \multicolumn{1}{c|}{} & Rychlost běhu & \multicolumn{2}{c|}{ F max (N) } \\
\hline Rovina & & průměr & SD \\
\hline Oboustranné bruslení jednodobé & tréninková & 907 & 163 \\
\hline & závodní & 1108 & 102 \\
\hline Oboustranné bruslení dvoudobé & tréninková & 843 & 105 \\
\hline & závodní & 1063 & 216 \\
\hline Stoupání & & & \\
\hline Oboustranné bruslení jednodobé & tréninková & 881 & 48 \\
\hline & závodní & 1013 & 38 \\
\hline Oboustranné bruslení dvoudobé & tréninková & 812 & 132 \\
\hline & závodní & 864 & 111 \\
\hline
\end{tabular}

Z výsledků je zřejmé, že hodnoty maximální vertikální síly na chodidle při stejných rychlostech běhu a typech terénu byly vždy mírně vyšší u bruslení oboustranného jednodobého. Vyšší hodnoty byly zjištěny také při běhu na rovině tréninkovou i závodní rychlostí ve srovnání se stoupáním u obou sledovaných technik. Tyto hodnoty se při běhu na rovině pohybovaly v rozmezí $843-1108 \mathrm{~N}$ a ve stoupání 812-1013 N. Velikost síly se zvýšila na rovině při závodní rychlosti ve srovnání s tréninkovou u bruslení oboustranného jednodobého o 22,2 \% a u dvoudobého o 26,1 \%. Ve stoupání činilo zvýšení $15,0 \%$ a 6,4 \%. Pokud srovnáme hodnoty maximální síly vytvořené v průběhu odrazu na rovině a ve stoupání při stejné rychlosti, byly zjištěny většinou rozdíly do $10 \%$, s výjimkou oboustranného bruslení dvoudobého při závodním tempu (23,0 \%). Při přepočtu maximální síly na násobek hmotnosti $(\mathrm{TH})$ byl tento koeficient při běhu závodní rychlostí na rovině i ve stoupání vždy vy̌̌ší než při tréninkové rychlosti (tab. 2).

Tab. 2 Koeficient síly vznikající na chodidle běžce vyjádřený násobky hmotnosti

\begin{tabular}{|c|c|c|c|c|}
\cline { 2 - 5 } \multicolumn{1}{c|}{} & \multicolumn{2}{c|}{ Rovina } & \multicolumn{2}{c|}{ Stoupání } \\
\cline { 2 - 5 } & $\begin{array}{c}\text { Tréninková } \\
\text { rychlost }\end{array}$ & $\begin{array}{c}\text { Závodní } \\
\text { rychlost }\end{array}$ & $\begin{array}{c}\text { Tréninková } \\
\text { rychlost }\end{array}$ & $\begin{array}{c}\text { Závodní } \\
\text { rychlost }\end{array}$ \\
\hline $\begin{array}{c}\text { Bruslení oboustranné dvou- } \\
\text { dobé }\end{array}$ & 1,2 & 1,5 & 1,2 & 1,4 \\
\hline $\begin{array}{c}\text { Bruslení oboustranné jed- } \\
\text { nodobé }\end{array}$ & 1,1 & 1,4 & 1 & 1,2 \\
\hline
\end{tabular}

\section{Rozdíly mezi sílou vytvořenou hlavní a vedlejší nohou při odrazu u bruslení oboustranného dvoudobého}

Oboustranné bruslení dvoudobé je jedinou technikou, u které můžeme smysluplně studovat a hodnotit rozdíly mezi silou vytvořenou jednotlivými dolními končetinami, protože zde při určité pohybové asymetrii dochází k rozdílům v zatěžování paží, trupu a dolních končetin při odrazu i odpichu. Proto 
označujeme dolní končetinu, která provádí odraz současně se soupažným odpichem, jako hlavní a druhou, která provádí odraz bez podpory soupažného odpichu, jako vedlejší (nebo silnější a slabší). Hodnoty silového působení hlavní nohy při odrazu byly vždy mírně vyšší než u vedlejší (Tab. 3). Na rovině při tréninkové rychlosti činil tento rozdíl $19,8 \%$ a při závodní $4,8 \%$. Ve stoupání byly rozdíly $9,5 \%$ při tréninkovém tempu a $13,0 \%$ při závodní rychlosti.

Násobky hmotnosti zatížení obou nohou byly většinou v rozsahu 1-1,2, s výjimkou běhu závodní rychlostí na rovině, kde pro hlavní nohu činilo zatížení 1,5násobek a pro vedlejší 1,4násobek TH.

Tab. 3 Hodnoty síly vytvořené hlavní a vedlejší nohou při bruslení oboustranném dvoudobém

\begin{tabular}{|c|c|c|c|c|c|c|c|c|}
\hline Terén & \multicolumn{4}{|c|}{ Rovina } & \multicolumn{3}{c|}{ Stoupání } \\
\hline Rychlost & \multicolumn{2}{|c|}{ tréninková } & \multicolumn{2}{|c|}{ závodní } & \multicolumn{2}{c|}{ tréninková } & \multicolumn{2}{c|}{ závodní } \\
\hline Dolní konč. & hlavní & vedlejší & hlavní & vedlejší & hlavní & vedlejší & hlavní & vedlejší \\
\hline Průměr & $919 \mathrm{~N}$ & $767 \mathrm{~N}$ & $1088 \mathrm{~N}$ & $1038 \mathrm{~N}$ & $853 \mathrm{~N}$ & $779 \mathrm{~N}$ & $912 \mathrm{~N}$ & $807 \mathrm{~N}$ \\
\hline SD & $131 \mathrm{~N}$ & $75 \mathrm{~N}$ & $282 \mathrm{~N}$ & $244 \mathrm{~N}$ & $174 \mathrm{~N}$ & $150 \mathrm{~N}$ & $177 \mathrm{~N}$ & $94 \mathrm{~N}$ \\
\hline
\end{tabular}

\section{Doba odrazu}

Doba odrazu se při zvýšení rychlosti zkrátila u obou technik na rovině i ve stoupání, jak je možné pozorovat $\mathrm{v}$ tabulce 3 .

Tab. 4 Doba odrazu u obou bruslařských technik

\begin{tabular}{|c|c|c|c|c|c|}
\cline { 3 - 6 } \multicolumn{2}{c|}{} & \multicolumn{2}{c|}{ Rovina } & \multicolumn{2}{c|}{ Stoupání } \\
\hline \multicolumn{2}{|c|}{ Technika / čas } & $\begin{array}{c}\text { Tréninková } \\
\text { rychlost (s) }\end{array}$ & $\begin{array}{c}\text { Závodní } \\
\text { rychlost (s) }\end{array}$ & $\begin{array}{c}\text { Tréninková } \\
\text { rychlost (s) }\end{array}$ & $\begin{array}{c}\text { Závodní } \\
\text { rychlost (s) }\end{array}$ \\
\hline Bruslení jednodobé & průměr & 0,41 & 0,27 & 0,33 & 0,3 \\
\hline & SD & 0,06 & 0,08 & 0,13 & 0,07 \\
\hline Bruslení dvoudobé & průměr & 0,54 & 0,33 & 0,27 & 0,26 \\
\hline & SD & 0,4 & 0,08 & 0,04 & 0,09 \\
\hline
\end{tabular}

Rozdíly $\mathrm{v}$ době odrazu jsou zřejmé mezi oběma technikami, i když rychlost běhu byla podobná (tab. 1). K významnému zkrácení doby odrazu při zvýšení rychlosti dochází především na rovině, pro bruslení oboustranné jednodobé o 34,1 \%, pro dvoudobé o $26,3 \%$. Ve stoupání jsou tyto změny podstatně menší, pro jednodobé o $9,1 \%$, pro dvoudobé o $3,7 \%$. Pokud srovnáme tyto dvě nejvýznamnější bruslařské techniky, potom byl při tréninkové i závodní rychlosti na rovině odraz prováděn u dvoudobého bruslení delší dobu než při jednodobém (1,3násobek a 1,2násobek času jednodobého). Ve stoupání se rozdíly v době odrazu mezi oběma technikami zkrátily, přičemž byl odraz při dvoudobém bruslení časově kratší než při jednodobém, a to jak při tréninkové, tak i závodní rychlosti (1,2násobek).

\section{Diskuze}

Srovnání s jinými studiemi je problematické, protože měření byla prováděna různými metodami a rozdílným př́istrojovým vybavením. Jednalo se většinou o terénní měření, při kterém podmínky nemohou být stejné, testování probíhalo v různém terénu, bud’ jen ve stoupání, nebo na rovině, a vždy jen jednou z technik. 
Jak na rovině, tak ve stoupání byly zaznamenány malé rozdíly mezi průměrem maximální síly na lyži u oboustranného bruslení jednodobého a dvoudobého. U žádné ze sledovaných technik volného způsobu běhu nedosáhla naše skupina podobných hodnot při běhu na rovině i ve stoupání, které uvádí např. Rusko (2003), tedy ve výši 1,5-2násobku hmotnosti. Ve srovnání s jinými studiemi byla maximální vertikální síla na lyži za celý odraz zaznamenána v podobné výši pro oboustranné bruslení dvoudobé, které uvádí Lindinger (1995)(0,8-1,3 NH), a mírně nižší než udává Smith (1989) při (1,4-1,5 NH).

Pokud srovnáme maximální sílu odrazu při bruslení na rovině a ve stoupání, je obvykle nižší při běhu ve stoupání u obou sledovaných technik. A pokud vycházíme z výsledků a závěrů některých jiných studií (Street, 1989), pro udržení maximální možné rychlosti ve stoupání je tř̌eba zvýšit podíl práce horních končetin u celkového výkonu, přičemž silové působení na podložku dolních končetin zůstává přibližně stejné, a zvyšuje se tedy nutně výkon horních končetin. Proto zjištěné vyšší hodnoty maximální síly na lyži při běhu na rovině mohou podporovat tvrzení (Street, 1989, Bilodeau, 1995, Ilavský, 2005), že při bruslení do kopce se mění poměr tvorby hybných sil dolními končetinami a pažemi až na 50:50 \%, i když je to individuální záležitost, protože tento poměr ovlivňuje především technika závodníka a jeho silové dispozice (zejména paží).

U bruslení oboustranného dvoudobého je asymetrie důsledkem provádění soupažného odpichu jen $\mathrm{s}$ jednou dolní končetinou, při kterém dochází $\mathrm{k}$ tvorbě větší hybné síly právě při odrazu hlavní nohou. K asymetrickému pohybu s větší torzí trupu, s většími rozdíly v odvratu mezi pravou a levou lyží, dochází ve stoupání. Na rovině je pohyb paží i dolních končetin více symetrický. Rozdíly v silovém působení na lyži oběma nohama ale nedosahují velikosti jako např. u Lidingera (1995), který zjistil velmi nevyrovnané zatížení dosahující rozdíl až $51 \%$. Také maximální síla dolních končetin při působení na podložku u Lindingera (1995) je nižší, především pro vedlejší nohu (613 N). U silnější nohy udává velikost 927 N, což je pro rychlý běh na rovině hodnota nižší o 13 \% a ve stoupání vyšší o 7 \% než u našich běžců. Síla vedlejší nohy byla u našich běžců vyšší na rovině o 68 \% a ve stoupání o 31 \% než v jeho studii.

Doba odrazu se u naší skupiny zkrátila se zvyšující se rychlostí běhu u obou sledovaných technik a při závodní rychlosti je na spodní hranici rozsahu (300-800 ms), který udává napřr. Rusko (2003). Smith $(1989,1992)$ zjistil delší dobu odrazu u oboustranného bruslení dvoudobého pro běh ve stoupání i na rovině, než vyplývá $\mathrm{z}$ našich měření. Doba odrazu při jeho výzkumu se pohybovala ve stoupání v rozmezí $0,7-0,85 \mathrm{~s}$ a na rovině $1,1-1,25 \mathrm{~s}$. To podle našeho výzkumu odpovídá spíše době celého skluzu jedné lyže.

\section{Závěry:}

Pro objektivizaci síly, kterou závodníci vytvářejí při odrazu dolními končetinami, jsme provedli měření u dvou nejvíce používaných technik volného způsobu běhu a srovnali je s již realizovanými studiemi. Byly zjištěny podobné hodnoty jako u jiných studií, i když nedošlo ke shodě se všemi autory.

Nalezli jsme odlišnosti ve výši maximální síly u obou technik při různých rychlostech a různém terénu. Především snížení hodnoty silového působení při odrazu ve stoupání proti běhu na rovině je důležitý poznatek pro tréninkový proces, protože poukazuje na potřebu vysoké úrovně silové připravenosti horní části těla, zejména paží.

Doba odrazu se u naší skupiny zkrátila s nárůstem rychlosti.

Rozdíly v síle mezi levou a pravou nohou u bruslení oboustranného dvoudobého jsou podstatně menší než u studie Lindingera (1995), což naznačuje lepší techniku našich probandů, vyrovnanější, rytmičtější, a tedy i ekonomičtější běh.

\section{Literatura}

Bellizzi,M.J., Kellin A.D.,King,S,K., Weyand.P.G.(1998) Does the application of ground force set the energetic cost of cross-country skiing? J. Appl.Physiol. 85 (5): 1736-1743.

Bilodeau,B. et al. (1996) Kinematics of cross country skiing. Med.Sci.Sports and Exerc. 28 (1), pp. 128-138. Ekstrom,H. (1981) Force interplay in cross-country skiing. In Scandinavian Journal of Sport Science, 3 (3): 69-76.

Ilavský,J., \& Suk,A. (2003) Běh na lyžích. Metodický dopis. SL ČR. s. 199. 
Hottenrott,K., \& Urban,V. (2004) Das grosse Buch vom Skilanglauf. Aachen, Meyer and Meyer.

Komi, P.V., Norman,R.W. (1987). Pre-loading in the thrust phase in cross-country skiing. International Journal of Sports Medicine, 8 (Suppl. 1):48-54.

Komi, P.V. (1987). Force measurement during cross-country skiing. International Journal of Sport Biomechanics, 3, 370-381.

Korvas, P. (2009) Vývoj rychlosti v běhu na lyžích na ženských světových soutěžích. Studia sportiva, 3 (2): $15-20$.

Leppavuori,A., Karras,M., Rusko,H., Viitasalo,T. (1993) A new method of measuring threedimensional reaction forces under the ski during cross-country skiing on snow.In Journal of Applied Biomechanics, 94, 315-328.

Lindinger,S., Muller,E.(1995) Biomechanische Beschreibung ausgewahlter moderner Skatingtechniken im Skilanglauf. Leistungssport, 25 (5):45 - 49.

Rusko, H. (2003) Cross Country Skiing. Blackwell Publishing, Oxford.

Smith,G.A., Nelson,R.C., Felman,A., Rankinen,J.L. (1989) Analysis of V1 skating technique of Olympic cross-country skiers. Int. Journal of Sport Biomechanics., 5(2):185-207.

Smith,G.A. (1992) Biomechanical analysis of cross-country skiing techniques. Med.Sci Sports Exerc. 24 : 1015-1022.

Street, G.M. (1989). Kinetic analysis of the V1 skate technique during rollerskiing. Medicine and Science in Sports and Exercise, $21: 79$. 